\title{
MICRO-FINANCE PROGRAMMES : GROWTH, ISSUES \\ AND CHALLENGES
}

* Saurabh Kumar

\begin{abstract}
The notion of Microfinance received an increased momentum in the after the World Summit for Social Development which was held in Copenhagen in 1995. The Copenhagen Summit emphasized the importance of improving access to credit for small producers, landless farmers, and rural women. But when we study about the credit for poverty alleviation, some questions needs to be answered. Is the mechanism of micro-finance viable in India? Microfinance offers savings, credit and insurance services to the poor especially rural women. However, it has been observed that in India women generally have limited or no control over their money, because husband or male family member makes all the important decisions in the family including economic decisions. This paper focuses on the experience of Micro-finance programmes in the Indian context. The paper portrays the limited access of credit to Indian rural women. The paper undertakes the study of various formal and informal finance institutions' activities in India such as Rural Bank, SEWA (Self Employed Women's Association) etc. The paper concludes with the belief that women's empowerment needs to be a counterpart of every governmental policy and empowerment cannot be assumed to be an outcome of one single programme. It must be incorporated and acknowledged in the planning procedure and economic policies.
\end{abstract}

Micro-Finance Programmes:

Growth, Issues and Challenges

Introductory Note

The notion of Microfinance received an increased momentum after the World Summit for Social Development which was held in Copenhagen in 1995. The Copenhagen Summit emphasized the importance of improving access to credit for small producers, landless farmers, and rural women. The World Micro Credit Summit at Washington in 1997 declared a global target of supporting more than 100 million of the world's poorest families with micro credit for self employment by the year 2005 (Nair 2001). But when we study about the credit for poverty alleviation, some questions need to be answered. Is the mechanism of micro-finance viable in India? Can NGO linked microfinance programmes avoid the shortcomings of a previous poverty alleviation programme like IRDP (Integrated Rural Development Programme) and institutionalize itself into a sustainable agenda for poverty alleviation?

* Research Scholar, Centre for International Politics, Organization and Disarmament

School of International Studies, Jawaharlal Nehru University, New Delhi -110067

saurabh1212@rediffmail.com Tel:09999733297,011-26741772 
In India women are couriterpart of the rural economic system, but it is a matter of pity that Indian national accounting system does not count their activities in the calculation of the Gross Domestic Product. Most of the women work in the informal economy and in this informal economic system, microfinance is becoming a relevant method to those who are marginalized, working poor and for those who are getting minimum or even sometimes nothing from the waged opportunities offered by different governmental schemes. Generally the livelihood options of the women are limited because of cultural and social restrictions and they have to take the responsibility of domestic work. Theoretically Microfinance offers them savings, credit and insurance services that can avoid these limitations. However, it has been observed that women generally have limited or no control over their money, because husband or male family member makes all the important decisions in the family including economic decisions. Apart from it, huge differences in literacy, property rights and social attitudes between man and women also limits impact outside the household and because of all above problems women residents of rural areas continue to have difficulties in accessing the benefits of Microfinance programmes. It is also noteworthy that women also bear the heavier workload created by the pressure and responsibility for loan and interest repayment.

By-definition "Microfinance can be referred to the small economic assistance for both credits and deposits and that is distributed to the people who are involved in the rural economic activities such as agriculture, farm production, fishing, operating micro-enterprise units where goods are produced, recycled, repaired, or traded; and also to those people who work for wages" (Srinivasan and Sriram 2003). The Declaration adopted in Micro credit and Microfinance summit which was held in
Washington, D. C. in 1997 defined micro finance programmes as those "extending small loans to poor people for self-employment projects that generate income, allowing them to care for themselves and their families; In most cases, microcredit projects offer a combination of services and resources to their clients in addition to credit for self-employment. These often include savings facilities, training, networking and peer support" (Micro-Credit Summit 1997). The National Bank for Agriculture and Rural Development (NABARD) defined micro-finance as the "provision of thrift, credit and other financial services and products of very small amounts to the poor in rural, semi-urban or urban areas enabling them to raise their income levels and improve living standards" (NABARD 2000).

In India major characteristic of the every Microfinance programmes is the marking of tiny, uncollateralized and short term credit to poor who are structured in mutually responsible groups. It is also noteworthy that in India almost every Microfinance programme targets women and they also have the explicit goal of empowerment. However, their key objectives and core agendas are different because that depends on the target of the programme. It is the argument of a school of thought that women are amongst the poorest and the most vulnerable of the deprived. While another school of thought urges that empowering women's capabilities will provide them choices, which are important in it, and also contribute to better economic growth and development. It is the argument of some scholars that a boost in woman's income results in higher well-being of the family, especially children. According to feminist point of view, access to economic assets and income presents a chance for better empowerment of women. Although every thought is based on the same opinion that woman empowerment is a vital development purpose for 
Microfinance programs, but it is very controversial and undecided that what women empowerment means? (Swain and Wallentin 2007). Women's empowerment can be referred to the continuous process by which the persons who are marginalized can get access to economic, social and political choices. This process not only includes resources but also decision making capacity, power to negotiate and ability to achieve the outcomes of this process (Kabeer 1999).

This paper focuses on the experience of Micro-finance programmes in the Indian context. The paper portrays the limited access of credit to Indian rural women. The paper takes study of various formal and informal finance institutions' activities in India such as Rural Bank, SEWA (Self Employed Women's Association) etc. The paper concludes with the belief that women's empowerment needs to be a counterpart of every governmental policy and empowerment cannot be assumed to be an outcome of one single programme. It must be incorporated and acknowledged in the planning procedure and economic policies.

\section{Problems of Rural Citizens}

In India there are many examples and evidence those point to a significant prospective of Micro-finance for empowerment. In many part of the country women's demand for credit is high; their savings propensity as well as the loan repayment rates are equal or in various cases exceeds those of men. Many institutions for example SEWA have also been successful in connecting members to macro-level gender encouragement and assisting women in financial matters. This made informal and rural sector women workers more noticeable in national and international policy debates. But still, there are shortcomings and questions about the access to savings and credit and empowerment, since in many cases Micro-finance programmes may have dis-empowered women, mainly the deprived. It especially seems to have occurred in programmes which have not explicitly considered gender issues. Rural women may simply be used as low-cost intermediaries between programme staff and male family members. The staff of micro financial institutions found it easy and more suitable to deal and negotiate with women because they are at home during working hours and they do not have tendency to oppose the conditions; while on the other hand male members of the family have taken loans on the names of women without their knowledge (Mayoux 2000).

In rural India women are bound to invest their money in men's economic activities because of male pressure. The basic problem is unemployment of men and and lack of income-earning opportunities which lead women to make a decision to invest their savings in men's activity or in their own business, so they choose the first one. There is one more problem which is related to the men's daily consumptions. Even if women start their business and start earning then men may be in charge of the women's financial earnings or may force women to utilize all their earnings for daily family expenses and this will allow men to utilize their individual earlier contributions to the household for their individual personal expenses such as alcohol consumption. This may be another serious problem because in that case men will become supporters and sympathizers of women's financial activities but in reality they were thinking about them self (Mayoux, 2000). Access to finance also changes the period of working hours between men and women in the same house or in the economic activity. Microfinance assists women but on the other hand it also increases the problem of working hours. Because of Microfinance the workloads of women have gone up. Now they have to do work for their economic activities and as well as they have to care about their routine household activities (ILO 2008). 


\section{Financial System in Rural India:}

It has been observed that in India that the development and reforms of the banking system remained isolated and was not made part of a broader socio-economic transformation in the countryside. In India land and agriculture reforms were explicit and have no direct connection with the reform of financial sector. Land remained inequitably distributed, and inequities in the access to credit followed the inequities in land distribution. This was because borrowers needed land as collateral in order to secure access to credit (Swamy 1979). However the Government has taken several initiatives to strengthen the institutional rural credit system but in practice these never became visible. It is mandatory in India that commercial banks are required to ensure that $40 \%$ of total credit is provided to the priority sectors out of which $18 \%$ in the form of direct finance to agriculture and $25 \%$ to priority sector in favour of weaker sections. But Indian banking system is quite different in real form. In India traditionally the formal sector Banking Institutions have been serving only the needs of the commercial sector and providing loans for middle and upper income groups. As far as the formal financial institutions are concerned, there are Commercial Banks, National Bank for Agriculture and Rural Development (NABARD), Regional Rural Banks (RRBs), Land Development Banks and Co-operative Banks. On the other hand informal financial service providers include mahajan, shetty and local bankers. In rural areas they dominate the financial activities.

In India Private and Foreign Banks have hardly any rural branches and even now they do not have intention to open branches in rural areas. On the other hand, from the 1990s after the opening of economy to connect it with global economic system, the public sector banks stopped their rural expansion and concentrated only on urban banking because now they are in the race with private and foreign banks. The population covered by a branch of public sector bank was 65000 in 1969 and now it has reached to less than 15000 . The rural Credit-Deposit ratio, which was near about 65 per cent in the 1980 s, has declined to less than 40 per cent at the beginning of 2000 . The share of small-scale industries and tiny business units in total bank credit declined from 13 per cent in 1990 to less than 5 per cent in 2002 (Ghosh 2005). The informal financial sources normally include funds available from family sources or local money lenders. The local money lenders charge very high rate of interest, generally ranging from $30 \%$ to $60 \%$ interest due to their monopoly in the absence of any other source of credit (Tiwari and Fahad 2004). There is a sharp rise in the share of moneylenders in informal sector advances from 27.2 percent in 1977 to 41.9 percent in 2000 (Ramachandran and Swaminathan 2001).

\section{Example of SEWA:}

SEWA (Self Employed Women's Association) started operation as a part of Ahmedabad's Textile Labour Association. It first began to organize urban working women outside the textile mills and outside the organized sector by helping them and raising voices in favour of demands for higher wages and better working conditions from employers and it also raised its voice for the protection from police brutality on the workers and poor working women. It rejected the conventional terms of informal and unorganized labor; its members called themselves self-employed. In 1972 SEWA was registered as a trade union of women workers able to agitate and advocate for their own well being and development. Registered in 1974, the SEWA Bank had 307558 numbers of accounts at the end of 2007-08. It has provided 32.45 crore Rupees as loan at the end of 2007-08 (SEWA Bank 2008). SEWA later added another dimension: support services targeted to its women members such as bidi workers, 
vegetable and fruit vendors. The Mahila SEWA Trust was opened in 1975 to support social services for its members. These include a maternal protection scheme to provide pre and postnatal services and food supplements, special training for midwives, creches, and literacy classes. Much of SEWA's growth comes from its ability to work in alliance with different parties at various levels of government. SEWA has often worked with various government agencies to develop and implement programs, as it had earlier in the banking field. Especially in rural areas, where government is now extending assistance to mothers and children, gifting dairy cattle to the poor, building and distributing smokeless cook-stoves, planting nurseries to combat deforestation, and regenerating wasteland by turning it over to the poor, SEWA has frequently assisted. The SEWA Bank has been granted permission to operate in rural areas in 1993 and now operating in the rural areas of ten districts of the Gujarat state of India. Such programmes increase the incomes of SEWA members and their families and expand the earning skills. SEWA also works with increasing effectiveness with various government and nongovernmental organizations. It has an agreement with the National Dairy Development Board, to provide training to women in dairy development, to recognize women's cooperative dairies, and to help persuade specific dairies to buy from only a single cooperative in each village (Spoodek 1994).

SEWA bank operates its activities through the chain of women which is structured in self-help groups. This chain of women brings together savings from the members and deposits it with the bank. The composition of this type of chain of women demonstrates the SEWA's efforts and commitment to organize women in rural India. In the groups women elect their own head and also give a name to their group. This chain works in several units and groups. Each group creates rules and regulations as to membership, savings, credit and administration. SEWA Bank educates the groups in matters of administration and accounting. When a group becomes regular in saving and administration almost after a year, it becomes eligible for borrowing. The credit approved is in the name of the group and is in direct proportion to its savings. However the group has the authority to decide the disbursement of the loan to the individual as well as it has the right to decide the amount of credit, interest and repayment schedule. The groups also rotate their own savings as loan (Hill 2008). SEWA Bank, which operates in ten districts of Gujarat, has Rs. 73.99 crore as total deposits now. Most of the working capital of the Bank comes from members' savings. The SEWA Bank borrower's repayment record is used, in lieu of collateral, to assess her creditworthiness (SEWA Bank 2008). But SEWA is also facing the problem of overdue. At the end of 1999, Non -Performing Advances amounted to 27 per cent of total loans and advances. SEWA has taken several steps to address the problem of overdue loans involve greater supervision and monitoring such as: daily targets for collection are being set and monitored, leaders from all areas are being called for weekly meetings, a special team of field workers has been created to regularly visit borrowers, and so on (Ramachandran and Swaminathan 2001).

\section{Example of Grameen Bank}

In the case of Grameen Bank of Bangladesh the defining criteria for the microfinance projects are the size of loans and the targeted population, particularly women, from low-income households. These loans are generally offered without any collateral. This programme is based on innovative financial practices (Chavan and Ramkumar 2002). In this case to obtain loans. 
potential borrowers must form a group of five, gather once a week for loan repayment meetings, and to start with, learn the bond rules and some certain decisions which they chant at the start of their weekly session. These decisions incorporate a code of conduct that members are encouraged to follow in their daily life e.g. production of fruits and vegetables in kitchen gardens, investment for improvement of housing and education for children, use of latrines and safe drinking water for better health, rejection of dowry in marriages etc. Physical training and parades are held at weekly meetings for both men and women and the rules and decision points are chanted as slogans. Though according to the Grameen Bank management, observance of these decisions is not mandatory, in actual practice it has become a requirement for receiving a loan (Papa et al, 2006). The Grameen Bank type system also contains some weak point and limitations. Grameen Bank has not oriented itself towards mobilizing rural people's resources. It has a repayment system of 50 weekly equal installments and that is not practical because rural women do not have a stable work and revenues source. Pressure for high repayment may drive rural women to money lenders that may create another problem as Micro-finance is a time consuming process (Tiwari and Fahad 2004).

\section{Example of Regional Rural Banks:}

To develop rural areas in India the policy of nationalization of commercial banks was launched in 1969. As well as there were the adoption of the directed lending programme, development of credit institutions such as Regional Rural Banks (RRBs), and implementation of the Integrated Rural Development Programme (IRDP), a credit-based poverty alleviation programme implemented through commercial banks (Shetty 1997). Regional Rural Banks (RRB) was established in 1975 with a goal to develop the rural economic structure. It was thought that these RRBs will enhance the productivity and capacity of agriculture, rural trade and small scale industries. The core intention was to provide credit and other banking facilities to the farmers, agricultural labourers, and small scale entrepreneurs because these were not getting the banking facilities of earlier banking system. RRBs achieved these targets up to some extent for example these banks were quite successful in the western part of Uttar Pradesh. RRBs alone have organised roughly 12 lakh self-help groups, 45 per cent of the total self-help groups in the country. RRBs have also issued over 40 lakh Kisan Credit Cards to the farmers (Bhatt and Thorat 2001). Despite their existence for over three decades, the role of the RRBs as an institutional reform in the field of rural credit is not satisfactory. The failure of the banks to bring the rural poor effectively under their network is attributed mainly to their policy of collateral-based lending. Such a policy, given the inequitable distribution of assets in the rural areas had resulted in the skewed distribution of institutional credit and access to it few extension of branches and lack of motivation of staff in rural areas is another major problem.

\section{Success and Failures:}

As far as the success of microfinance programmes is concerned it depends on: the formation of small homogeneous borrowing groups that build on prior traditional informal networks in the village; the ability to deny access to future credit in the event of default by member; and a common bond other than credit and prior experience in group activities. An element in the success of some programmes has been the preponderance of group lending schemes. Group lending drastically cuts down transaction costs. Secondly, group lending cuts down on borrowers costs like collateral registration, transportation costs, etc. The Grameen Bank, the Zimbabwe Agricultural Finance Corporation lend only to established groups. Group lending by entailing a joint liability redices the risk of default and also 
does away with the requirement of physical collateral. which the poor are often unable to provide (Jha 2000). In case of India the problem starts with the smallness of the fund provided by the credit institutions in the name of microfinance. The NABARD Task Force recommended that the average loan given to members of self-help groups be around Rs. 1,000. There are problems of lack of accountability and transparency, high transaction costs and increasing share of non performing loans.

\section{CONCLUSION}

It is noteworthy that NGO and Self Help Group linked micro finance does not present a complete and permanent solution for the problems of rural poverty. It is not a mechanism for mobilizing large-scale funds for traditional change in the rural areas of India, as well as it cannot displace the informal sector in short term or defeat the historical flaws of rural economy completely. But that does not mean that these programmes are ineffective, what is considered necessary is a long-term supportive and scientific approach, with performance criteria to review rural progress and requirements.

However a lot of studies have been done which intended to remove the shortcomings of existing rural financing system, yet some of the major suggestions are as follows: there must be establishment of more micro-finance projects and expansion of Regional Rural Banks. The institutional mechanism envisaged for the disbursal of micro-finance is Non Governmental Organizations (NGO) and Regional Rural Banks. Micro-finance, by its very nature, cannot attempt to meet the full range of the demand for credit in the whole rural area but whatever it will cover that will be bonus for development process. NGO linked micro-finance is, however, expected to incur more transactions costs and achieve a lower repayment record than the formal banking sector in respect of small-scale, short-term loans but for the social development, economic gains must be ignored up to some extent. Regional Rural Banks can also play a very crucial role and they can do well to work with local governments and self-help groups for the development of rural areas. Regional Rural Banks have advantages in respect of small-scale rural credit that NGOs lack. They need more staff, proper training and most importantly motivation to improve the social and economic conditions of rural people particularly rural women. Private institutions such as private banks, foreign banks and private financial companies musi be encourage a to work in rural areas and for the social development of rural women. Private investors will not move towards villages until they will not get benefit so there must be some incentives for them such as Tax holiday, rebate in duties, low rates of land for the establishment of new projects, and low interest rates. Compulsory law and regulation may force them to work in rural areas but that will not be helpful in long term.

Leach and Sitaram (2002); and Cornwall and White (2000) stated that there is no such thing as a women's project or women oriented programmes. The question is: how can such projects, which are intended to empower women, be designed and implemented so as to ensure that male involvement is constructive rather than destructive? They have offered some suggestions about it. In the initial stages, both the men and the women should be given some familiarization with the project's goals and requirements, there should be a greater effort to develop an understanding among the men of why only the women were to be involved. The training programme needed to give greater importance to raising awareness about gender relations, among the men as well as the women. Even if it was unable to involve them directly in the project the benefits of the project for the men should have been clearer to them. 
To alleviate poverty central bank can set sound macroeconomic policy that provides stability and low inflation. Central bank must adjust bank regulation to facilitate deposit taking by Microfinance institutions. Another major change must be done in the national accounting systems which is not counting the contribution of women. Much of the women's economic activities takes place in the informal sector, in home based production, petty trading, and agriculture. That type of work is still invisible in national labor force and employment statistics. The expansion of Micro-finance projects, Regional Rural Banks and increment in social and economic conditions of rural women is not possible until women empowerment is not the integral part of national planning policies and budgets. The notion of empowerment is not static it is dynamic. It is control over income and assets, ability to generate effective demand, capability to make choices, access to political, and social, judicial and economic resources. It is a process and also infinite outcome. State, political parties, national and international institutions, NGO, academia and media can fill the gap which exists right now between empowerment and rural women. Governments can also play a pivotal role in this process. The aim should be to make and ensure permanent access to finance for the poor people especially rural women. For this government must create a microfinance friendly policy environment, develop financial infrastructure, and support social intermediation.

\section{REFERENCES}

Bhatt, Nitin and Y. S. P. Thorat (2001), "India's Regional Rural Banks: the Institutional Dimension of Reforms", Journal of Microfinance, 3(1), pp. 65-88.

Buvinic, Mayra (1997), "Women in Poverty: A New Global Underclass" Foreign Policy, No. 108, Autumn, 1997, pp. 38-53.

Ghosh, Jayati (2005), "Bank Nationalization: The Record", People's Democracy, Vol. XXIX, No. 31, July 2005.

Hill, Elizabeth (2008), "India: The Self Employed Women's Association and autonomous organizing" in Kaye Broadbent and Michele Ford (eds.) Women and Labour Organizing in Asia: Diversity, Autonomy and Activism, Routledge: London.

ILO (2008), "Small Change, Big Changes: Women and Microfinance", [Online web] Accessed on November 1, 2008, URL: http://www.ilo.org/gender/ Events/lang-en/docName-WCMS_091581/ index.htm.

Kabeer, Naila (1999) "Resources, Agency, Achievements: Reflections on the Measurement of Women's Empowerment", Development and Change, Vol. 30, pp. 435-464.

Kabeer, Naila (2008), Mainstreaming Gender in Social Protection for the Informal Economy, Commonwealth Secretariat: London.

Mayoux, Linda (2000), "Micro-finance and the Empowerment of Women: A Review of Key Issues", [Online web] Accessed on November 1, 2008, URL: http://www.ilo.org/public/english/employment/ finance/download/wpap23.pdf.

Mayoux, Linda (2003), "Sustainable Learning for Women's Empowerment: Ways Forward in Micro-Finance", New Delhi: Samskriti. 
Papa, Michael. J.; Mohammad A. Auwal and Arvind Singhal (2006), "Dialectic of Control and Emancipation in Organizing for Social Change: A Multitheoretic Study of the Grameen Bank in Bangladesh", Communication Theory, Vol.5, No.3, March 2006, pp. 189-223.

Ramachandran, V. K. and Madhura Swaminathan (2001), "Does Informal Credit Provide Security? Rural Banking Policy in India", [Online web] Accessed on November 1, 2008, URL: http:// www. oit.org/public/english/protection/ses/ download/docs/2india.pdf.

SEWA Bank (2008), "Financial Data of SEWA Bank," [Online web] Accessed on November 5 , 2008, URL: http://www.sewabank.com/ financialdata.htm.

Spodek, Howard (1994), "The Self-Employed Women's Association in India: Feminist, Gandhian Power in Development", Economic Development and Cultural Change, Vol. 43, No. 1, October 1994, pp. 193-202.

Srinivasan, R. and M. S. Sriram (2003), "Microfinance: An Introduction", IIMB Management Review, June 2003, IIM Bangalore Publication.

Swain, Ranjula Bali and Fan Yang Wallentin (2007), "Does Microfinance Empowerment Women? Evidence from Self Help Groups in India", Uppsala University Working Paper Series, No. 2007:24, Uppsala University.

Tiwari, P. and S. M. Fahad (2004), "Microfinance Institutions in India", [Online web] Accessed on November 1, 2008, URL: http://www.gdrc.org/icm/ conceptpaper-india.html.
NABARD (2000), "Task Force on Supportive Policy and Regulatory Framework for Micro finance in India: Summary and Recommendations", [online web] Accessed on November 1, 2008, URL: www.nabard.org/whats/whats.htm.

Micro Credit Summit (1997), "Declaration and Plan of Action", [online web] Accessed on November 1 , 2008, URL: www.microcreditsummit.org/ decalaration.htm.

Leach, Fiona and Shashikala Sitaram (2002), "Microfinance and Women's Empowerment: A lesson from India", Development in Practice, Vol. 12, No. 5, Nov. 2002, pp 575-588.

Cornwall, A. and S. White (2000), "Men, Masculinities and Development: Politics, Policies and Practice", IDS Bulletin, No. 31 (2), pp 1-6.

Nair, Tara S. (2001), "Institutionalizing Microfinance in India: An Overview of Strategic Issues", Economic and Political Weekly, Vol.36, No. 4, 27 Jan- 2 Feb 2001, pp 399-404.

Swamy, Dalip S. (1979), "Land and Credit Reforms in India", Social Scientist, No. 8 (11), pp 3-13.

Shetty, S. L. (1997), "Financial Sector Reforms in India: An Evaluation”, Prajnan, No. 25 (3-4), pp 253287.

Chavan, Pallavi and R. Ramkumar (2002), "MicroCredit and Rural Poverty: An Analysis of Empirical Evidence", Economic and Political Weekly, Vol. 37 , No. 10, Mar. 9-15, 2002, pp 955-965.

Jha, Ashish kumar (2000), "Lending to the Poor: Designs for Credit", Economic and Political Weekly, Vol. 35, No. 8/9, Feb. 26, 2000, pp 606-609. 